\title{
Evaluation of Liver Biopsy Findings and Comparison with Noninvasive Fibrosis Scores in Patients with Non-Alcoholic Steatohepatitis
}

\author{
Non-Alkolik Steatohepatitli Hastalarda Karaciğer Biyopsi Bulgularının \\ Değerlendirilmesi ve Noninvazif Fibroz Skorları ile Karşılaştırılması
}

\author{
EImas BIBERCI KESKIN ๑, Ganime COBAN ๑
}

Ethics Committee Approval: This study approved by the Bezmialem Vakif University, Non-invasive Clinical Studies Ethic Committee, 22 October 2019, 20/381.

Conflict of interest: The authors declare that they have no conflict of interest.

Funding: None.

Informed Consent: Not Applicable
Cite as: Biberci Keskin E, Coban G. Evaluation of liver biopsy findings and comparison with noninvasive fibrosis scores in patients with non-alcoholic steatohepatitis. Medeniyet Med J. 2019;34:354-9.

\begin{abstract}
Objective: Nowadays, the incidence of non-alcoholic fatty liver and steatohepatitis (NASH) is increasing and early diagnosis is of great importance. In this study, we investigated the place of Fibrosis-4 (FIB-4), Aspartate Aminotransferase to Platelet Ratio (APRI) and AST/ALT Ratio in predicting liver fibrosis and its most optimal cut-off value in NASH patients undergoing liver biopsy.

Method: Patients with NASH who underwent liver biopsy were included in the study. Biopsy results of all patients were evaluated histopathologically and grade of fibrosis was graded. In addition, FIB-4, APRI and AST/ALT scores were calculated and compared with biopsy findings in these patients.

Results: A total of 88 patients were included in the study. Of these patients 51 (58\%) were female and the mean age of the study population was 52.7 99.5. According to biopsy results, NASH was detected in $79(89.8 \%)$ and NAFLD in 9(10.2\%) patients. The cut-off values of $<0.47$ for APRI and $<0.88$ for FIB-4 scores showed the best discriminatory power in exclusion of liver fibrosis. Likewise, the cut-off value greater than 0.68 for APRI score and $>2.16$ for FIB-4 score showed the highest predictive value in predicting advanced fibrosis. AST/ALT ratio had not any diagnostic value.

Conclusion: FIB-4 and APRI scores play an important role in the noninvasive prediction of fibrosis in NASH patients, but the AST/ALT ratio is not sufficient. On the other hand, although the guidelines recommend using these scoring systems as a screening tool, there is no clarity as to the appropriate ideal cut-off values. At this point, FIB-4 score stands out with high sensitivity and specificity especially in the prediction of severe fibrosis.
\end{abstract}

Keywords: Steatohepatitis, FIB-4, APRI, liver, fibrosis

Öz

Amaç: Günümüzde non-alkolik karaciğer yağlanması ve steatohepatit (NASH) sıklığı giderek artmakta olup, erken tanı büyük önem tasımaktadır. Calıșmamızda karaciğer biyopsisi yapılan NASH hastalarında Fibrozis-4 (FIB-4), Aspartat Aminotransferaz Trombosit Oranı (APRI) ve AST/ ALT oranı skorlarının karaciğer fibrozunu öngörmedeki yerini ve en uygun kestirim değerlerini araștırdık.

Yöntem: Karaciğer biyopsisi yapılan NASH hastaları çalışmaya dahil edildi. Tüm hastaların biyopsi sonuçları histopatolojik olarak değerlendirildi ve fibrozis dereceleri evrelendirildi. Aynı şekilde bu hastalarda FIB-4, APRI ve AST/ALT skorları hesaplanarak biyopsi bulguları ile karsslasstırıldı.

Bulgular: Çalışmaya toplam 88 hasta alındı. Bu hastaların 51 'i (\%58) kadın olup ortalama yaş $52,7 \pm 9,5$ idi. Biyopsi sonuçlarına göre hastaların 79'unda $(\% 89,8) \mathrm{NASH}$, 9'unda ise $(\% 10,2)$ NAFLD tespit edildi. Karaciğer fibrozunun ekarte edilmesinde APRI skoru için $<0,47$, FIB-4 skoru için ise $<0,88$ kestirim değeri en yüksek prediktif değere sahipti. Aynı şekilde ileri fibrozun öngörülmesinde ise APRI skoru için >0,68, FIB-4 skoru için ise $>2,16$ kestirim değeri en yüksek prediktif değeri gösterdi. AST/ALT oranının ise tanısal değeri olmadığı görüldü.

Sonuç: NASH hastalarında fibrozun noninvazif olarak öngörülmesinde FIB-4 ve APRI skorlarının önemli bir yeri vardır, ancak AST/ALT oranı yeterli değildir. Öte yandan her ne kadar klavuzlar bu skorlama sistemlerini taramada önerse de uygun ideal kestirim değerleri konusunda netlik yoktur. Bu noktada FIB-4 skoru özellikle ciddi fibrozun öngörülmesinde yüksek duyarlılık ve özgüllük ile ön plana çıkmaktadır.

Anahtar kelimeler: Steatohepatit, FIB-4, APRI, karaciğer, fibroz
Received: 6 November 2019

Accepted: 7 December 2019 Online First: 26 December 2019

Corresponding Author:

E.B. Keskin

ORCID: 0000-0002-5528-830X Bezmialem Vakıf University, Faculty of Medicine, Department of Gastroenterology, Istanbul, Turkey

elmasbiberci@yahoo.com

\section{G. Coban}

ORCID: 0000-0002-5779-6797 Bezmialem Vakıf University, Faculty of Medicine, Department of Pathology, Istanbul, Turkey 
E. Biberci Keskin and G. Coban, Evaluation of Liver Biopsy Findings and Comparison with Noninvasive Fibrosis Scores in Patients with NonAlcoholic Steatohepatitis

\section{INTRODUCTION}

Non-alcoholic fatty liver disease (NAFLD) and non-alcoholic steatohepatitis (NASH) are the most important causes of liver disease of unknown etiology that show histological characteristics similar to alcoholic liver disease ${ }^{1,2}$. In the last decade, it has been demonstrated that NAFLD which is a hepatic finding of metabolic syndrome occurs considerably more frequently in obese and diabetic individuals ${ }^{3}$. In addition, it is clear that an increase in the number of the components of metabolic syndrome increases the risk of progression to $\mathrm{NASH}^{4}$. It has been estimated that approximately $25 \%$ of the world population have NAFLD ${ }^{5}$. Nonalcoholic fatty liver disease is characterized with presence of hepatic steatosis, hepatocyte injury, ballooning in hepatocytes along with 5\% inflammation with or without fibrosis ${ }^{6}$. Detecting fibrosis either using imaging or biopsy is critical in terms of prognosis in such patients as advanced fibrosis in NASH leads to higher mortality with hepatic and cardiovascular complications ${ }^{7,8}$.

Currently, discrimination of simple steatosis from steatohepatitis and fibrosis depends on the findings in histological examination of liver biopsy specimens. On the other hand, liver biopsy is an invasive method which may lead to complications $^{9,10}$. In addition, use of liver biopsy in the diagnosis of NASH is neither practical nor cost-effective. Therefore, different noninvasive clinical and laboratory scores such as NAFLD fibrosis, Fibrosis-4 (FIB-4) and aspartate aminotransferase (AST) to platelet ratio (APRI) index are developed and currently in use for predicting the existence of fibrosis ${ }^{11}$. These scores have been widely used to predict liver fibrosis ${ }^{12}$. The guideline of The European Association for the Study of the Liver (EASL) recommends use of these scores to exclude advanced fibrosis ${ }^{13}$. Similarly, the guideline of the American Association for the Study of Liver Diseases (AASLD) supports appropriateness of these scores to be used for defining advanced fibrosis in $\mathrm{NASH}^{14}$. The controversial point is the difference in cut-off values that determine diagnostic accuracy of these scores ${ }^{12,13}$. Therefore, in our study, we wanted to determine the role of FIB-4, APRI and AST/ALT ratio scores in predicting fibrosis in patients with NASH who had undergone liver biopsy, and also to determine the most appropriate cut-off values of these scores.

\section{MATERIAL and METHOD}

This study approved by the Bezmialem Vakif University, Non-invasive Clinical Studies Ethics Committee, on October 22, 2019 with the decision no: $20 / 381$.

This study was planned as a retrospective study. Patients aged above 18 years who had undergone liver biopsy due to presumed NASH and who were followed up between January 2012 and June 2019 in our university gastroenterology outpatient clinic were included in the study. Exclusion criteria consisted of alcoholic liver disease, druginduced liver disease, autoimmune hepatitis, viral hepatitis, cholestatic, metabolic or genetic liver diseases, malignancy, autoimmune diseases, heart failure and pregnancy. In addition, patients with incomplete data were excluded from the study.

\section{Liver biopsy}

Liver biopsy specimens were evaluated independently by two pathologists working in our university. When these two pathologists were contradictory, a decision was made by consulting a third pathologist. The definition of NASH was based on the AASLD guideline which necessitates the presence of $5 \%$ hepatic steatosis with inflammation and hepatocyte injury (ballooning) with or without fibrosis ${ }^{14}$. The definition NAFLD: was based on the AASLD guideline which requires the presence of $5 \%$ hepatic steatosis without evidence of hepatocellular injury and/or fibrosis ${ }^{14}$. The degree of histological activity and the stage of fibrosis were evaluated and graded accordingly. The evaluation of fibrosis was made according to NASH-CRN (non-alcoholic steatohepatitis - clinical research 
network) scoring system in which a score of 3 and above was considered as advanced fibrosis ${ }^{15}$ (Figure 1).

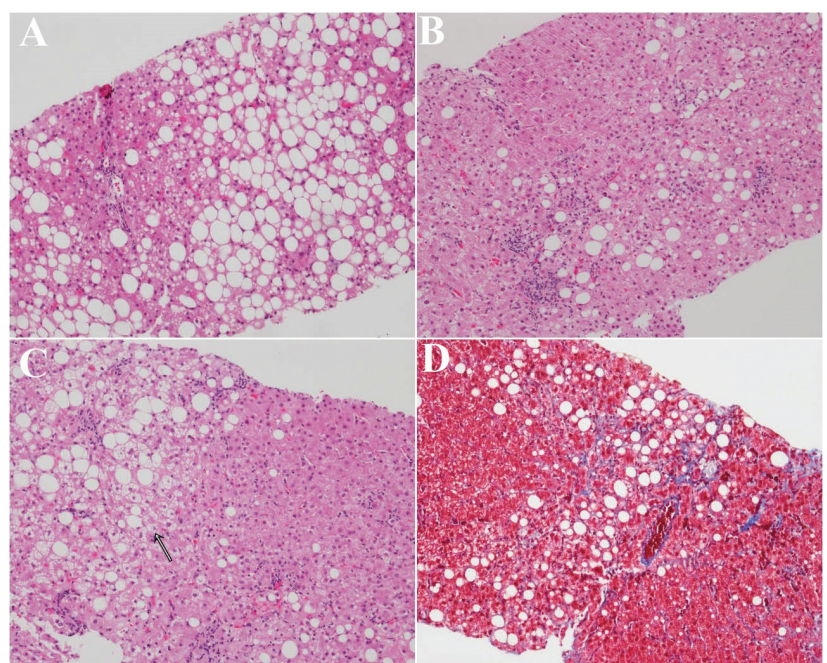

Figure 1. A; Steatosis of the liver parenchyma, B; Lobular inflammation due to mononuclear cell infiltration, $C$; Ballooning degeneration of hepatocytes (arrow), D; Regions of pericellular fibrosis seen under Masson Trichome staining (x 100).

\section{Fibrosis scores}

APRI score was calculated using a formula that incorporate serum AST and platelet values ${ }^{16}$. The second score was AST/ALT ratio ${ }^{17}$. FIB-4 score was calculated using four parameters including the platelet count, age, serum AST and ALT ${ }^{18}$.

\section{Statistical Analysis}

The distribution of the continuous variables was evaluated for normality by the Shapiro Wilk test. If a variable has normal distribution, its descriptive statistical characteristics were expressed as mean \pm standard deviation. Otherwise, the descriptive statistics were expressed as median and interquartile range. The categorical data were given as frequencies and percentages. Receiver operating characteristic curve (ROC) analysis was performed to analyze the diagnostic performances of FIB-4, APRI and AST/ALT scores. The optimal binary cut-off values for the two scores in our sample were identified by calculating the Youden

Table 1. Baseline clinical characteristics, laboratory and biopsy findings of the study patients.

\begin{tabular}{|c|c|c|c|}
\hline & $\begin{array}{l}\text { Descriptive Statistics } \\
\text { mean } \pm \text { SD or } n(\%)\end{array}$ & & $\begin{array}{l}\text { Descriptive Statistics } \\
\text { mean } \pm \text { SD or } n(\%)\end{array}$ \\
\hline Patients $(n=88)$ & $52.70 \pm 9.54$ & NASH Fibrosis Stage (biopsy) & \\
\hline Age (years) & & & $7(9.0 \%)$ \\
\hline Gender & & Stage 0 & $48(61.2 \%)$ \\
\hline Female & $51(58 \%)$ & Stage 1 & $16(20.1 \%)$ \\
\hline Male & $37(42 \%)$ & Stage 2 & $6(7.2 \%)$ \\
\hline Diabetes Mellitus & $23(27.7 \%)$ & Stage 3 & $1(1.3 \%)$ \\
\hline AST (IU/L) & $51.6 \pm 36.5$ & Stage 4 & \\
\hline ALT (IU/L) & $78.5 \pm 47.5$ & & \\
\hline ALP (IU/L) & $88.8 \pm 37.8$ & Steatohepatitis grade (biopsy) & \\
\hline GGT (IU/L) & $61.3 \pm 38.1$ & Grade 0 & $1(1.3 \%)$ \\
\hline Glucose (mg/dl) & $131.3 \pm 45.3$ & Grade 1 & $28(36.4 \%)$ \\
\hline WBC $\left(\times 10^{3}\right)$ & $7.7 \pm 1.9$ & Grade 2 & 15 (19.5\%) \\
\hline HGB (g/dL) & $13.9 \pm 1.8$ & Grade 3 & $5(6.5 \%)$ \\
\hline Platelet $\left(\times 10^{3}\right)$ & $238.7 \pm 89.1$ & Grade 4 & $18(23.4 \%)$ \\
\hline HOMA IR & $40.2 \pm 74.8$ & Grade 5 & $8(10.4 \%)$ \\
\hline Triglyceride (mg/dL) & $191.14 \pm 118.14$ & Grade 6 & $2(2.6 \%)$ \\
\hline LDL-cholesterol (mg/dL) & $147.31 \pm 42.56$ & Hepatosteatosis grade by USG & \\
\hline APRI score & $0.81 \pm 0.77$ & Grade 1 & $39(44.3 \%)$ \\
\hline FIB-4 score & $1.58 \pm 1.26$ & Grade 2 & $37(42 \%)$ \\
\hline Pathological Diagnosis & & Grade 3 & $12(13.6 \%)$ \\
\hline NAFLD & $9(10.2 \%)$ & & \\
\hline $\mathrm{NASH}$ & $79(89.8 \%)$ & & \\
\hline
\end{tabular}

AST: aspartate aminotransferase; ALT: alanine aminotransferase; ALP: alkaline phosphatase; GGT: Gamma-glutamyl transferase; WBC: white blood cell; HGB: hemoglobine; HOMA IR: HOMA insulin resistance; NAFLD: Non-alcoholic fatty liver disease: NASH: non-alcoholic steatohepatitis 
E. Biberci Keskin and G. Coban, Evaluation of Liver Biopsy Findings and Comparison with Noninvasive Fibrosis Scores in Patients with NonAlcoholic Steatohepatitis

J index. The diagnostic performance of each score for three different fibrosis levels (any fibrosis, moderate fibrosis, severe fibrosis) were assessed. The sensitivity, specificity, positive (PPV), and negative predictive values (NPV) for each test were also calculated. All analyses were conducted with the SPSS version 22.0 (IBM Corp., USA). P value less than 0.05 was considered as statistically significant.

\section{RESULTS}

A total of 88 patients were included in the study. Fifty-one patients (58\%) were female and the mean age of the study population was $52.7 \pm 9.5$ years. Twenty-three patients ( $27.7 \%$ ) had diabetes mellitus. The demographic data are shown in Table 1. According to liver ultrasonography, grade 1 , 2 and 3 steatosis were found in $44.3 \%, 42 \%$ and $13.6 \%$, of the patients, respectively. Liver biopsy findings were consistent with NASH in 79 (89.8\%) patients and NAFLD in the remaining 9 (10.2\%) patients. Among the patients with a diagnosis of NASH, fibrosis was absent in $7.9 \%$ of the patients, while grade $1(n=48 ; 61.5 \%), 2(n=16 ; 20.5 \%), 3$ $(n=6 ; 7.7 \%)$, and $4(n=1 ; 1.3 \%)$ fibrosis were found in respective number (\%) of patients.

The mean FIB-4 index was $1.58 \pm 1.26$ and the mean APRI score was $0.81 \pm 0.77$. The AUC value, sensitivity, specificity, positive and (PPV) and ne- gative predictive values (NPV) for FIB-4 index with a cut-off value of $<0.88$ (used to exclude fibrosis) were $0.78,75 \%, 80 \%, 98 \%$ and $20 \%$ respectively. The corresponding values for a FIB-4 index cut-off value of $>2.16$ (used to predict severe fibrosis) were found to be $0.95,94 \%, 90 \%, 73 \%$ and $98 \%$ respectively (Table 2 and Figure 2 ).
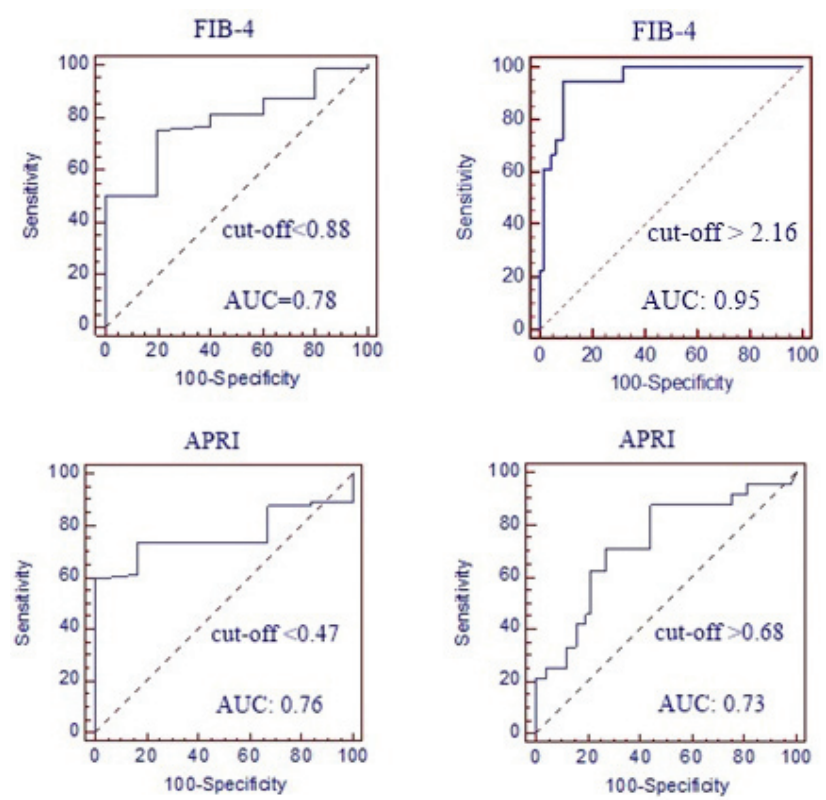

Figure 2. ROC analysis of FIB-4 and APRI scores.

The AUC value, sensitivity, specificity, PPV and NPV for APRI score at a cut-off value of $<0.47$ (exclusion of fibrosis) were 0.76, 59\%, 100\%, 100 and 18 , respectively. The corresponding values for an APRI score cut-off value of $>0.68$ which was used

Table 2. Receiver operator curve analysis of three risk scores regarding the fibrosis in liver.

\begin{tabular}{|c|c|c|c|c|c|c|c|}
\hline & Cut off & Sensitivity (\%) & Specificity (\%) & PPV (\%) & NPV (\%) & AUC & $\mathbf{P}$ \\
\hline \multicolumn{8}{|l|}{ FIB-4 } \\
\hline Any Fibrosis & $<0.88$ & 75 & 80 & 98 & 20 & 0.78 & 0.0012 \\
\hline Moderate Fibrosis & $>1.8$ & 38.10 & 95.83 & 80 & 78 & 0.67 & 0.0134 \\
\hline Severe Fibrosis & $>2.16$ & 94.44 & 90.90 & 73.9 & 98.4 & 0.95 & $<0.001$ \\
\hline \multicolumn{8}{|l|}{ APRI } \\
\hline Any Fibrosis & $<0.47$ & 59.38 & 100 & 100 & 18.8 & 0.76 & $<0.001$ \\
\hline Severe Fibrosis & $>0.68$ & 70.83 & 73.08 & 54.8 & 84.4 & 0.73 & 0.0004 \\
\hline \multicolumn{8}{|l|}{ AST/ALT } \\
\hline Any Fibrosis & $<0.46$ & 87.14 & 50 & 95.3 & 25 & 0.63 & 0.360 \\
\hline Severe Fibrosis & $>0.72$ & 71.43 & 69.57 & 19.2 & 96 & & 0.157 \\
\hline
\end{tabular}

FIB-4: fibrozis-4 index; APRI: aspartate aminotransferase to platelet ratio; PPV: positive predictive value, NPV: negative predictive value; AUC: Area under curve 
to predict severe fibrosis were $0.73,70 \%, 73 \%$, $54.8 \%$ and $84 \%$ respectively (Table 2 ). The AST/ ALT ratio was not found to be statistically significant in predicting fibrosis (Table 2 and Figure 2; $p=0.36$ for ruling out any fibrosis and $p=0.15$ for predicting severe fibrosis).

\section{DISCUSSION}

The current study has shown that the FIB-4 index could be used as a screening and diagnostic test particularly indicating that a FIB-4 index cut-off value of $>2.16$ had a higher diagnostic accuracy in determining presence of advanced fibrosis. A FIB-4 index cut-off value of $<0.88$ was the best threshold to exclude fibrosis with a PPV of $98 \%$. An APRI score cut-off value of $<0.47$ was diagnostic for ruling out fibrosis with a PPV of 100 percent. An APRI score cut-off value of $>0.68$ was moderately diagnostic for severe fibrosis with a PPV of 54 percent.

The results of the current study related to clinical benefits of the FIB-4 index and APRI score have contributed to identification of fibrosis. The AASLD guideline also noted clinical benefit of the FIB-4 index and APRI score in identification of fibrosis ${ }^{14}$. Kaya $\mathrm{E}$ et al. ${ }^{19}$ asserted that the noninvasive tests such as FIB-4 and NAFLD fibrosis score could be used to exclude rather than to predict severe liver fibrosis. On the other hand, the AASLD guideline demonstrated that the NFS or FIB-4 index was clinically beneficial in defining NAFLD patients with severe fibrosis.

Presence of advanced fibrosis is the strongest indicator of liver-related events. Therefore, it is important to detect NASH patients with hepatic fibrosis. Although serum enzymes are used to screen underlying liver disease, some individuals with NASH and individuals with advanced fibrosis will have normal liver enzymes. In our study, the AST/ALT ratio was not found to be statistically significant in predicting fibrosis, either.
Siddiqui et al. ${ }^{20}$ evaluated the accuracy of noninvasive methods in detecting hepatic fibrosis and the changes in fibrosis in patients with histologically proven NASH. It was claimed that the diagnostic accuracies of FIB-4, NFS and APRI were higher in terms of detecting severe fibrosis compared to other parameters. However, it was advocated that these scores could be used in clinical practice to exclude presence of moderate and advanced fibrosis, because they have higher negative predictive values. FIB-4 and APRI scores were found to have the highest accuracy in predicting progression to severe fibrosis and a high negative predictive value among all noninvasive scores. The results were similar to the results of our study.

Adams LA et al. ${ }^{21}$ compared the accuracies of simple and complex models of fibrosis in predicting hepatic fibrosis in a multicenter study. Simple APRI, BARD (Body mass index, AST, ALT, diabetes) and complex HEPASCORE (age, gender, bilirubin, gamma glutamyl transferase, hyaluronic acid, a-2 macroglobulin), FIBROTEST (age, gender, bilirubin, gamma glutamytrans), FIB-4 fibrosis models were evaluated in patients with NAFLD who underwent liver biopsy. Simple models included considerably more parameters compared to complex models. Therefore, complex models have greater number of significant appropriate diagnostic properties compared to simple models in terms of detecting fibrosis. However, it was claimed that the general accuracy of these models was moderate and they predicted fibrosis with a low positive predictive value. In our study, we compared simple and complex scores. We found that the complex model FIB-4 index was more significant in predicting severe fibrosis in the diagnosis and screening.

Our study had some limitations. It was a retrospective study with a relatively low number of patients. We could also use other scores such as complex scores NAFLD fibrosis score, Hepascore, and Fibrotest. 
E. Biberci Keskin and G. Coban, Evaluation of Liver Biopsy Findings and Comparison with Noninvasive Fibrosis Scores in Patients with NonAlcoholic Steatohepatitis

\section{CONCLUSION}

The FIB-4 and APRI scores currently have an important place in predicting fibrosis non-invasively in NASH patients. However, the AST/ALT ratio was not found to be statistically significant. Although guidelines recommend these scoring systems for screening, appropriate cut-off values have not been determined yet. The demographic properties of the patients included, duration of disease and the size of the study cohort influence these measurements. At this point, the FIB-4 index stands out with its high specificity and sensitivity.

\section{REFERENCES}

1. Younossi Z, Anstee QM, Marietti M, et al. Global burden of NAFLD and NASH: trends, predictions, risk factors and prevention. Nat Rev Gastroenterol Hepatol. 2018;15:11 20. [CrossRef]

2. Younossi ZM, Stepanova M, Rafiq N, et al. Nonalcoholic steatofibrosis independently predicts mortality in nonalcoholic fatty liver disease. Hepatol Commun. 2017;1:421428. [CrossRef]

3. Chalasani N, Younossi Z, Lavine JE, et al. The diagnosis and management of nonalcoholic fatty liver disease: Practice guidance from the American Association for the Study of Liver Diseases. Hepatology. 2018;67:328-357. [CrossRef]

4. Golabi P, Otgonsuren $M$, de Avila L, Sayiner M, Rafiq N, Younossi ZM. Components of metabolic syndrome increase the risk of mortality in nonalcoholic fatty liver disease (NAFLD). Medicine (Baltimore). 2018;97:e0214. [CrossRef]

5. Younossi ZM, Koenig AB, Abdelatif D, Fazel Y, Henry L, Wymer M. Global epidemiology of nonalcoholic fatty liver disease-Meta-analytic assessment of prevalence, incidence, and outcomes. Hepatology. 2016;64:73-84. [CrossRef]

6. Adams LA, Lymp JF, St Sauver J, et al. The natural history of nonalcoholic fatty liver disease: a population-based cohort study. Gastroenterology. 2005;129:113-21. [CrossRef]

7. Tuten MF, Ozdamarlar U, Yilmabasar MG, Kutlu Y, Hayirlioglu DA, Kuru LI. Correlation of histopathological and MRI findings in non-alcoholic fatty. Goztepe Tip Dergisi. 2014;29:82-87. [CrossRef]

8. Ekstedt M, Franzén LE, Mathiesen UL, et al. Long-term follow-up of patients with NAFLD and elevated liver enzymes. Hepatology. 2006;44:865-73. [CrossRef]
9. Cadranel JF, Rufat P, Degos F. Practices of liver biopsy in France: results of a prospective nationwide survey. For the Group of Epidemiology of the French Association for the Study of the Liver (AFEF). Hepatology. 2000;32:47781. [CrossRef]

10. Ratziu V, Charlotte F, Heurtier A, et al. Sampling variability of liver biopsy in nonalcoholic fatty liver disease. Gastroenterology. 2005;128:1898-906. [CrossRef]

11. Kaswala DH, Lai M, Afdhal NH. Fibrosis Assessment in Nonalcoholic Fatty Liver Disease (NAFLD) in 2016. Dig Dis Sci. 2016;61:1356-64. [CrossRef]

12. Guha IN, Parkes J, Roderick P, et al. Noninvasive markers of fibrosis in nonalcoholic fatty liver disease: Validating the European Liver Fibrosis Panel and exploring simple markers. Hepatology. 2008;47:455-60. [CrossRef]

13. European Association for the Study of the Liver (EASL); European Association for the Study of Diabetes (EASD); European Association for the Study of Obesity (EASO). EASL-EASD-EASO Clinical Practice Guidelines for the management of non-alcoholic fatty liver disease. J Hepatol. 2016;64:1388-402. [CrossRef]

14. Chalasani N, Younossi Z, Lavine JE, et al. The diagnosis and management of nonalcoholic fatty liver disease: Practice guidance from the American Association for the Study of Liver Diseases. Hepatology. 2018;67:328-357. [CrossRef]

15. Kleiner DE, Brunt EM, Van Natta $M$, et al. Design and validation of a histological scoring system for nonalcoholic fatty liver disease. Hepatology. 2005;41:1313-21. [CrossRef]

16. Kruger FC, Daniels CR, Kidd M, et al. APRI: a simple bedside marker for advanced fibrosis that can avoid liver biopsy in patients with NAFLD/NASH. S Afr Med J. 2011;101:477-80.

17. Sheth SG, Flamm SL, Gordon FD, Chopra S. AST/ALT ratio predicts cirrhosis in patients with chronic hepatitis $C$ virus infection. Am J Gastroenterol. 1998;93:44-8. [CrossRef]

18. Sterling RK, Lissen E, Clumeck N, et al. Development of a simple noninvasive index to predict significant fibrosis in patients with HIV/HCV coinfection. Hepatology. 2006;43:1317-25. [CrossRef]

19. Kaya E, Bakir A, Kani HT, Demirtas CO, Keklikkiran C, Yilmaz Y. Simple Noninvasive Scores Are Clinically Useful to Exclude, Not Predict, Advanced Fibrosis: A Study in Turkish Patients with Biopsy-Proven Nonalcoholic Fatty Liver Disease. Gut Liver. 2019 Sep 19. [CrossRef]

20. Siddiqui MS, Patidar KR, Boyett S, Luketic VA, Puri P, Sanyal AJ. Performance of non-invasive models of fibrosis in predicting mild to moderate fibrosis in patients with nonalcoholic fatty liver disease. Liver Int. 2016;36:572-9. [CrossRef]

21. Adams LA, George J, Bugianesi E, et al. Complex noninvasive fibrosis models are more accurate than simple models in non-alcoholic fatty liver disease. J Gastroenterol Hepatol. 2011;26:1536-43. [CrossRef] 